Ethiopian Journal of Environmental Studies \& Management 9(Suppl. 1): 852 - 864, 2016.

ISSN:1998-0507

doi: http://dx.doi.org/10.4314/ejesm.v9i1.5S

Submitted: June 01, 2016

Accepted: November 22, 2016

\title{
SOCIO - ECONOMIC AND ENVIRONMENTAL IMPACT OF ARTISANAL MINING IN PARTS OF NARAGUTA SHEET 168, NORTH CENTRAL NIGERIA
}

\author{
*DIBAL, H.U., ${ }^{1}$ EMOUBOME, E., ${ }^{1}$ LEKMANG., I.C. ${ }^{1}$ AND MALLO, S.J. ${ }^{2}$ \\ ${ }^{1}$ Department of Geology, University of Jos, Nigeria \\ ${ }^{2}$ Department of Mining Engineering, University of Jos, Nigeria
}

\begin{abstract}
The aim of this study was to assess the socio - economic and environmental impact of artisanal mining in parts of Naraguta Sheet 168. Geochemical data, environmental analysis from previous studies and on the spot interviews and interactions were employed to obtain the data for this study. Results revealed over 5000 abandoned pits with varying depths ranging from 12 to 15 meters. Analysis of soils and water samples collected from the mining pits, some hand dug wells and boreholes in the area, indicate low levels of most trace and rare earth elements in the waters. However, individual elements concentration showed that farm soils generally have high levels of $\mathrm{Pb}$ and Th and in some places $\mathrm{Cd}$. The calculated Index of geo-accumulation classified the soils as uncontaminated to moderately contaminated. With over 5000 pits already dug in the area, the arable lands have been devastated, with diversion in flow directions of most streams. Trees and shrubs have been uprooted rendering the land susceptible to erosion. Opened mined pits serve as death traps to animals and breeding grounds for mosquitoes, making the area prone to malaria disease. About N450, 000 (3000 Dollars) at the end of every week is obtained from sales of the ore, shared amongst $8-10$ team members. However, the social vices associated with it, such as child labour, school drop-out, the use of drugs, deaths due to flooding and collapse of lotto pits, theft, inflation, and prostitution, sexually transmitted diseases is prevalent. The study suggest interventions such as; reclaiming open pits, dredging of streams, rivers and remediation of contaminated soils and health awareness campaign to ameliorate the negative impacts of artisanal mining on the communities.
\end{abstract}

Key Words: Artisanal Mining, Trace Elements, Land Degradation, Tin Mining

\section{Introduction}

The mining industry in Nigeria has great potential (Mallo, 2012). It has the capacity to contribute to local and foreign exchange earnings as well as attracting direct foreign investment into the country's economy. However, this has been hampered by inconsistencies in monetary and fiscal policies of the government. This problem consequently encouraged the insurgence of Artisanal, (Small scale) miners whose activities are largely informal. It is a highly unregulated sector and subject to harsh working and living conditions. This activity is practiced on a small scale by people who are often poor and often do not realize that the methods they use are potentially risky to life, the environment, the economy and their health. Artisanal

*Corresponding Author: Dibal, H.U.

Email: dibalu@unijos.edu.ng 
mining activities have stripped thousands of square kilometers of top soil and arable land across the Jos Plateau (Mallo, 2012). Consequently, forest, animals, fish habitats and natural water resources have been damaged or destroyed. The aim of this work is to determine the socio economic impact of artisanal in parts of Naraguta Sheet 168 NE (Bismarck and Darkoh, 2001; Samuel et al., 2016; Kitula, 2005; Stephen, 2008).

\section{Description of Study Area}

The study area falls within the following coordinates latitude $9^{\circ} 40^{\prime} \mathrm{N}-$ $\mathrm{N} 9^{\circ} 44^{\prime} \mathrm{N}$ and longitude $\mathrm{E} 8^{\circ} 51^{\prime}-\mathrm{E} 8^{\circ 0} 53^{\prime}$ (Fig 1). General Geology of the study area Kuru is generally characterized by the abundant occurrence of the Younger Granite rocks which were emplaced during the Jurassic era. The formation of the Younger Granite is associated with the hot spot magmatism. The rock bodies are massif occurring ring complexes. The Younger Granites are known for hosting tin and columbite within Jos Bukuru and environs. It covers a total area of about $20 \mathrm{~km}^{2}$. With a total of six artisanal mining clusters (Fig.1), the area is highly devastated (Mallo, 2012).The geology of the Jos - Bukuru Complex has been excellently treated by (Buchanan et al., 1971; Macleod et al., 1971; Turner, 1976).

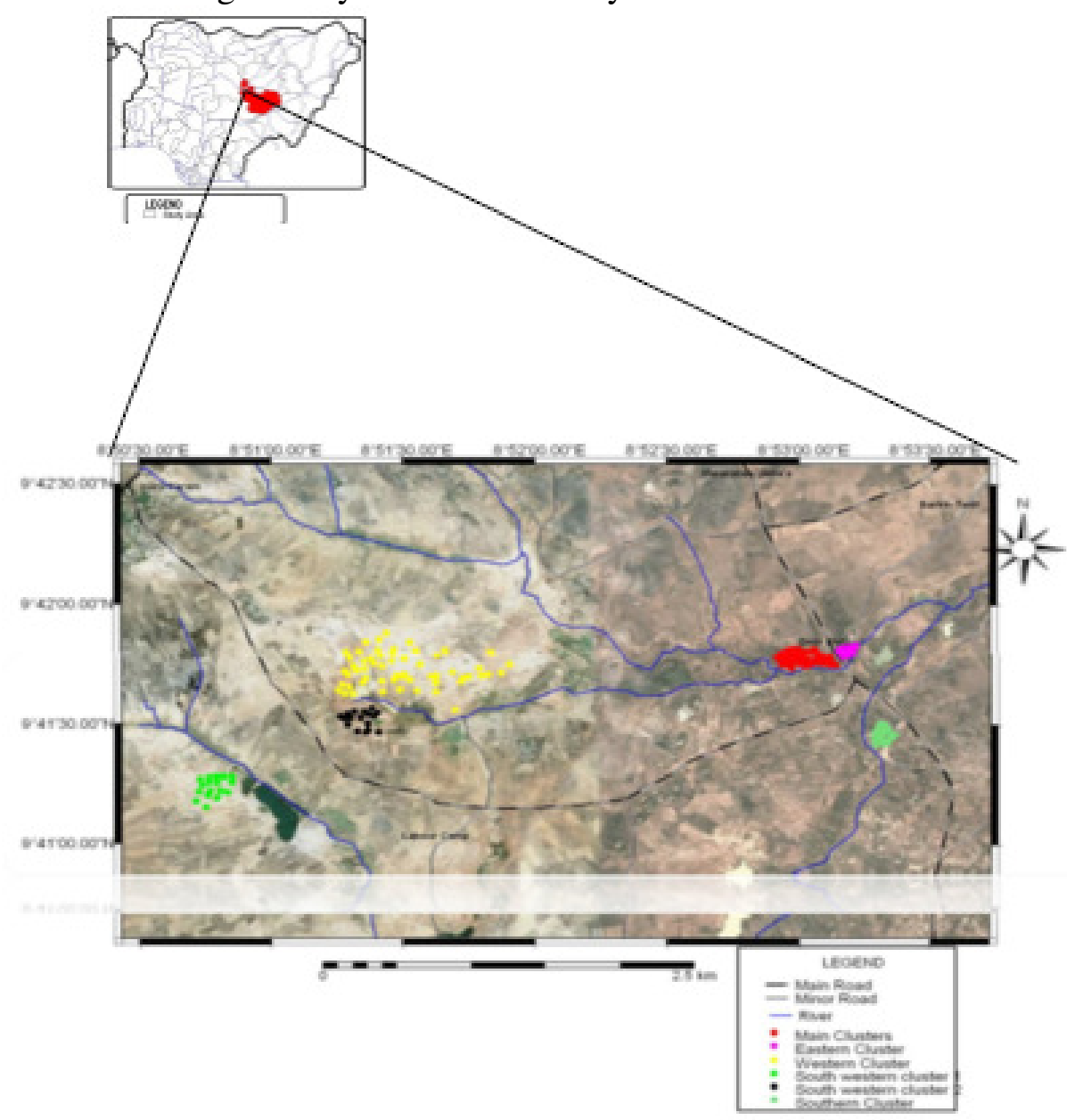

Figure 1: Satellite image showing mining clusters within Kuru and environs 


\section{Methodology}

Water and Soil Sampling: Systematic sampling of mine ponds, water wells, boreholes (hand pumped) and streams within the study area was carried out. Water samples were collected in a 1 liter plastic (one) screw cap bottles. The plastic bottles used in collection of samples were first rinsed with the water to be sampled 3 times after which concentrated nitric acid $\left(\mathrm{HNO}_{3}\right)$ was added to the sample water (about 2 drops) for preservation. In-situ tests were carried out for conductivity, temperature and $\mathrm{pH}$, using a simple Oakton $\mathrm{pH} 5 / 6$ conductivity meter with an accuracy level of 1 . Ground water from boreholes was pumped before samples were collected to eliminate stagnant water within the pipes. Soil samples were collected in polythene rubber bags from farms within the locations. The soil samples were pulverized into fine powder, using the agate mortar and put in sealed polyethene bags. A total of sixteen water samples (2 - mine water, 5 - dam water, 2 - stream water and 2 - well water). Both soil and water samples were analysed at the ACME laboratory in Canada. The ICPMS method was used for both soils and water. Locations of sample collection points were taken using an Etrex Garmin Global Positioning System (G.P.S). Geochemical data from previous work were also collated and synthesized.

Interviews: Additional information during the course of the work was obtained from individuals, miners, (team/groups) through interviews. Information obtained includes:

- Amount of ore obtained per hole and income generated per hole per day
- Common forms of illnesses within the mining environment and their individual home.

- Cost of living within the mining sites and their homes, prices of vegetables and meat.

- Commonly noticeable problem within the environment, erosion, flooding.

- Availability of water.

- Dangers encountered during the mining activity inside the lotto pits.

- Drug problems

This information was provided through interviewing individuals encountered within and around the mining community during the course of the study.

\section{Results and Discussion}

Compositions of the Waters: Table 1 and 2 show the compositions of rare earth, trace and major ions in the waters of the study area. Among the rare earth elements only Sc showed values below detection limit for all water points in the study area. Few of the sampling points showed values below detection for $\mathrm{Ce}$, $\mathrm{Eu}, \mathrm{Pr}, \mathrm{Ho}, \mathrm{Lu}$ and Tm. However, $\mathrm{Ce}$ in the water ranges from $<0.01-10.01$ ppb, Dyranges from 0.01 - 0.92, Er has values ranging from $0.01-0.64 \mathrm{ppb}, \mathrm{Gd}$, $0.02-1.11 \mathrm{ppb}, \mathrm{La}, 0.02-5.29 \mathrm{ppb}, \mathrm{Nd}$ ranges from $0.04-5.28 \mathrm{ppb}, \operatorname{Pr}<0.01-$ 1.27, Ho $<0.01-0.20 \mathrm{ppb}, \mathrm{Lu}<0.01-$ $0.14 \mathrm{ppb}, \mathrm{Sm} 0.02-1.02 \mathrm{ppb}, \mathrm{Tb}<0.01$ $-0.16 \mathrm{ppb}, \mathrm{Tm}<0.01-0.14 \mathrm{ppb}, \mathrm{Y} 0.15$ - $6.31 \mathrm{ppb}, \mathrm{Yb} 0.01$ - $098 \mathrm{ppb}$. With respect to water sources, the dam, mine and stream waters seem to have higher values for some of the rare earth elements than the hand dug wells and the boreholes. Perhaps this may be due to the discharge of the mined waters flowing into the streams, and the surface waters draining into the ponds. 
Table 1: Compositions of rare earth elements in the waters of the study area

\begin{tabular}{|c|c|c|c|c|c|c|c|c|c|c|c|c|c|c|c|c|c|c|}
\hline ELEMENTS & & $\mathrm{Lu}$ & Sc & $\mathrm{Sm}$ & $\mathrm{Tb}$ & Th & $\mathrm{Tm}$ & $\mathrm{Y}$ & $\mathrm{Yb}$ & $\mathrm{Ce}$ & Dy & $\mathrm{Er}$ & $\mathrm{Eu}$ & $\mathrm{Gd}$ & $\mathrm{La}$ & $\mathrm{Nd}$ & $\mathrm{Pr}$ & Ho \\
\hline MDL & & 0.01 & 1 & 0.01 & 0.02 & 0.05 & 0.01 & 0.01 & 0.01 & 0.01 & 0.01 & 0.01 & 0.01 & 0.01 & 0.01 & 0.01 & 0.01 & 0.01 \\
\hline & WATER & & & & & & & & & & & & & & & & & \\
\hline \multirow[t]{16}{*}{ COORD } & SOURCE & & & & & & & & & & & & & & & & & \\
\hline & Mine water & 0.07 & $<1$ & 0.7 & 0.15 & 0.05 & 0.07 & 5.54 & 0.42 & 4.71 & 0.81 & 0.43 & 0.16 & 0.92 & 4.08 & 3.73 & 1 & 0.19 \\
\hline & Dam & 0.03 & $<1$ & 0.28 & 0.07 & 0.05 & 0.03 & 1.74 & 0.13 & 2.35 & 0.31 & 0.18 & 0.05 & 0.38 & 1.27 & 1.54 & 0.42 & 0.07 \\
\hline & Stream & $<0.01$ & $<1$ & 0.11 & 0.02 & 0.05 & 0.01 & 0.79 & 0.09 & 0.73 & 0.12 & 0.07 & $<0.01$ & 0.09 & 0.49 & 0.41 & 0.11 & 0.03 \\
\hline & Mine water & 0.14 & $<1$ & 0.53 & 0.09 & 0.05 & 0.14 & 5.07 & 0.98 & 2.51 & 0.75 & 0.64 & 0.07 & 0.55 & 2.94 & 2.72 & 0.69 & 0.17 \\
\hline & Dam & 0.06 & $<1$ & 0.36 & 0.06 & 0.05 & 0.05 & 3.29 & 0.36 & 2.64 & 0.4 & 0.3 & 0.04 & 0.39 & 1.61 & 1.73 & 0.46 & 0.09 \\
\hline & Dam & 0.02 & $<1$ & 0.13 & 0.02 & 0.05 & 0.02 & 1.25 & 0.13 & 1.26 & 0.16 & 0.11 & 0.02 & 0.15 & 0.7 & 0.83 & 0.21 & 0.04 \\
\hline & Hand Dug Well & $<0.01$ & $<1$ & $<0.02$ & $<0.01$ & 0.05 & 0.01 & 0.66 & 0.03 & $<0.01$ & 0.03 & 0.04 & $<0.01$ & 0.02 & 0.02 & 0.04 & $<0.01$ & 0.01 \\
\hline & Hand Dug Well & $<0.01$ & $<1$ & $<0.02$ & $<0.01$ & 0.05 & $<0.01$ & 0.15 & 0.01 & 0.03 & 0.01 & 0.01 & $<0.01$ & 0.02 & 0.08 & 0.06 & $<0.01$ & $<0.01$ \\
\hline & Borehole & $<0.01$ & $<1$ & 0.03 & 0.01 & 0.05 & $<0.01$ & 0.84 & 0.03 & 0.22 & 0.05 & 0.05 & $<0.01$ & 0.04 & 0.19 & 0.17 & 0.05 & 0.01 \\
\hline & Dam & 0.01 & $<1$ & 0.1 & 0.02 & 0.05 & 0.01 & 1.16 & 0.09 & 0.7 & 0.16 & 0.11 & 0.02 & 0.13 & 0.42 & 0.43 & 0.12 & 0.03 \\
\hline & Dam & 0.02 & $<1$ & 0.15 & 0.03 & 0.05 & 0.02 & 1.28 & 0.08 & 1.08 & 0.15 & 0.11 & 0.03 & 0.17 & 0.65 & 0.79 & 0.19 & 0.03 \\
\hline & Stream & 0.01 & $<1$ & 0.2 & 0.03 & 0.05 & 0.02 & 1.42 & 0.13 & 1.25 & 0.17 & 0.12 & 0.01 & 0.17 & 0.74 & 0.77 & 0.2 & 0.04 \\
\hline & Stream & $<0.01$ & $<1$ & 0.09 & 0.02 & 0.05 & $<0.01$ & 0.53 & 0.05 & 1.06 & 0.09 & 0.03 & $<0.01$ & 0.1 & 0.55 & 0.52 & 0.11 & 0.01 \\
\hline & Dam & 0.06 & $<1$ & 1.02 & 0.16 & 0.05 & 0.06 & 6.31 & 0.38 & 10.01 & 0.92 & 0.03 & 0.19 & 1.11 & 5.29 & 5.28 & 1.27 & 0.2 \\
\hline & Borehole & $<0.01$ & $<1$ & 0.09 & 0.01 & 0.05 & $<0.01$ & 0.46 & 0.04 & 0.78 & 0.08 & 0.04 & 0.02 & 0.08 & 0.4 & 0.51 & 0.12 & 0.02 \\
\hline
\end{tabular}


The trace elements in the waters (Table 2) As, B, Bi, Cd, Cr, Ge, Hf, Hg, In, Mo, Ta, Te, Th, Ti, Pd, Pt, Re, Rh, $\mathrm{Rn}, \mathrm{S}, \mathrm{Sn}$ have values below the detection limits. Values of 0.05 and 0.13 of $\mathrm{Zr}$ have been detected in the surrounding waters. Ag in the waters has values ranging from $<0.05-0.31 \mathrm{ppb}$, Al 3.3 - $560 \mathrm{ppb}$. Higher values are recorded in the surface waters and lower in the ground waters. Ba ranges from $7.62-144.9 \mathrm{ppb}$ with no clear variations in the differentsources. Be ranges from ranging from $<5 \mathrm{ppb}-82 \mathrm{ppb}$. All the ground water sources have values below detection limits. Co ranges from $0.02-$ $3.44 \mathrm{ppb}, \mathrm{Cs} 0.02-1.01 \mathrm{ppb}, \mathrm{Cu} 0.1-$ $125.2 \mathrm{ppb}, \mathrm{Fe}$ (Iron) < $10-4.59 \mathrm{ppb}, \mathrm{Li}$ $0.2-4.4 \mathrm{ppb}, \mathrm{Mn} 0.01-0.35 \mathrm{ppb}, \mathrm{U}$, $0.013-3.13 \mathrm{ppb}, \mathrm{Zn}$ ranges from $0.8-$ 314.2 ppb. Major elements, $\mathrm{Ca}, \mathrm{Na}, \mathrm{Mg}$ and $\mathrm{K}$ in the water ranges from $0.88-$ $40.40,1.24-12.44,0.09-1.57$ and 0.56
- 3.76 ppm respectively. One would expect the trace and rare earth elements (R.E.E's) to be very high in waters of the area, owing to the mineralized nature of the Younger Granites Rocks (tin and columbite) with associated Zircon and thorite minerals. However, Zirconium, thorium and Niobium are virtually absent in the waters. This may be because of the insolubility of their minerals. Since the host rock for these minerals have been found to be enriched in these radioactive elements (Solomon, 2007) probably, the waters although depleted in these elements may be found to be radioactive.

Compositions of the Farm Soil samples: The composition of the major, trace and rare earth elements for the farm soils samples are presented in Table 3. Index of geo-accumulation calculated for some of the trace elements are presented in figures (1-4). As, U, Au, Sb, Bi, S are all below detection limit (Table 3). 
Table 2: Geochemical compositions of farm soils in the study area

\begin{tabular}{|c|c|c|c|c|c|c|c|c|c|c|c|c|c|c|}
\hline & & Elements & $\mathrm{La}$ & $\mathrm{Cr}$ & $\mathrm{Mg}$ & $\mathrm{Ba}$ & $\mathrm{Ti}$ & $\mathrm{Al}$ & $\mathrm{Na}$ & $\mathrm{K}$ & $\mathrm{W}$ & $\mathrm{Zr}$ & $\mathrm{Sn}$ & $\mathrm{Y}$ \\
\hline Coordinates & Source & Units & $\mathrm{Ppm}$ & Ppm & $\%$ & Ppm & $\%$ & $\%$ & $\%$ & $\%$ & ppm & $\mathrm{ppm}$ & ppm & $\mathrm{Ppm}$ \\
\hline $9^{\mathrm{O}} 41.466 \mathrm{~N} 8^{\mathrm{O}} 52.560 \mathrm{E}$ & Farm soil & & 48.00 & 44.00 & 0.08 & 330.00 & 0.51 & 5.59 & 0.07 & 1.81 & $<4.00$ & 183.00 & 7.00 & 36.00 \\
\hline $9^{\mathrm{O}} 41.571 \mathrm{~N} 8^{\mathrm{O}} 52.000 \mathrm{E}$ & Farm soil & & 13.00 & 24.00 & 0.01 & 18.00 & 0.09 & 1.95 & 0.03 & 0.23 & $<4.00$ & 152.00 & 4.00 & 20.00 \\
\hline $9^{\mathrm{O}} 41.265 \mathrm{~N} 8^{\mathrm{O}} 52540 \mathrm{E}$ & Farm soil & & 25.00 & 52.00 & 0.07 & 79.00 & 0.35 & 5.94 & 0.02 & 0.38 & $<4.00$ & 79.00 & 6.00 & 15.00 \\
\hline \multirow[t]{3}{*}{$9^{\mathrm{O}} 40.345 \mathrm{~N} 8^{\mathrm{O}} 51.522 \mathrm{E}$} & Farm soil & & 47.00 & 47.00 & 0.08 & 155.00 & 0.56 & 7.24 & 0.03 & 0.54 & $<4.00$ & 142.00 & 6.00 & 30.00 \\
\hline & & Elements & $\mathrm{Pb}$ & $\mathrm{Zn}$ & $\mathrm{Ag}$ & $\mathrm{Ni}$ & $\mathrm{Co}$ & Mn & $\mathrm{Fe}$ & As & $\mathrm{U}$ & $\mathrm{Au}$ & Th & $\mathrm{Sr}$ \\
\hline & & Units & Ppm & Ppm & Ppm & Ppm & Ppm & $\mathrm{ppm}$ & ppm & ppm & ppm & ppm & ppm & Ppm \\
\hline $9^{\mathrm{O}} 41.466 \mathrm{~N} 8^{\mathrm{O}} 52.560 \mathrm{E}$ & Farm soil & & 34.00 & 64.00 & $<0.50$ & 17.00 & 6.00 & 275.00 & 2.59 & $<5.00$ & $<2.00$ & $<4.00$ & 34.00 & 45.00 \\
\hline $9^{\mathrm{O}} 41.571 \mathrm{~N} 8^{\mathrm{O}} 52.000 \mathrm{E}$ & Farm soil & & 59.00 & 49.00 & $<0.50$ & 5.00 & $<2.00$ & 125.00 & 1.78 & $<5.00$ & $<2.00$ & $<4.00$ & 58.00 & 4.00 \\
\hline $9^{\mathrm{O}} 41.265 \mathrm{~N} 8^{\mathrm{O}} 52540 \mathrm{E}$ & Farm soil & & 21.00 & 45.00 & 1.00 & 20.00 & 7.00 & 97.00 & 2.74 & $<5.00$ & $<2.00$ & $<4.00$ & 12.00 & 20.00 \\
\hline \multirow[t]{3}{*}{$9^{\mathrm{O}} 40.345 \mathrm{~N} 8^{\mathrm{O}} 51.522 \mathrm{E}$} & Farm soil & & 30.00 & 57.00 & 0.70 & 25.00 & 7.00 & 99.00 & 3.61 & $<500$ & $<2.00$ & $<4.00$ & 25.00 & 31.00 \\
\hline & & Elements & $\mathrm{Nb}$ & $\mathrm{Be}$ & $\mathrm{Sc}$ & $\mathrm{S}$ & Mo & $\mathrm{Cu}$ & $\mathrm{Cd}$ & $\mathrm{Sb}$ & $\mathrm{Bi}$ & V & $\mathrm{Ca}$ & $\mathrm{P}$ \\
\hline & & Units & Ppm & Ppm & Ppm & Ppm & Ppm & ppm & ppm & ppm & ppm & ppm & $\%$ & $\%$ \\
\hline $9^{\mathrm{O}} 41.466 \mathrm{~N} 8^{\mathrm{O}} 52.560 \mathrm{E}$ & Farm soil & & 107.00 & 3.00 & 6.00 & $<0.10$ & 2.00 & 13.00 & 0.50 & $<5.00$ & $<5.00$ & 60.00 & 0.11 & 0.04 \\
\hline $9^{\mathrm{O}} 41.571 \mathrm{~N} 8^{\mathrm{O}} 52.000 \mathrm{E}$ & Farm soil & & 194.00 & 1.00 & 2.00 & $<0.10$ & $<2$ & 7.00 & $<0.40$ & $<5.00$ & $<5.00$ & 33.00 & 0.01 & 0.01 \\
\hline $9^{\mathrm{O}} 41.265 \mathrm{~N} 8^{\mathrm{O}} 52540 \mathrm{E}$ & Farm soil & & 77.00 & 4.00 & 7.00 & $<0.10$ & 2.00 & 15.00 & $<0.40$ & $<5.00$ & $<5.00$ & 61.00 & 0.02 & 0.03 \\
\hline $9^{\mathrm{O}} 40.345 \mathrm{~N} 8^{\mathrm{O}} 51.522 \mathrm{E}$ & Farm soil & & 100.00 & 3.00 & 9.00 & $<0.10$ & 7.00 & 22.00 & 0.50 & $<5.00$ & $<5.00$ & 107.00 & 0.02 & 0.09 \\
\hline
\end{tabular}


$\mathrm{Pb}$ ranges in the soils from $7-22 \mathrm{ppm}$, three (3) of the sampling sites have values above the crustal average of 13 ppm. $\mathrm{Zn}$ ranges from $45-64 \mathrm{ppm}$. These values are below the crustal average of 70 ppm. Soil samples from both farms in Kuru Jantar have $\mathrm{Cd}$ above the crustal average of $0.2 \mathrm{pm}$. La values in farm soils in Kuru Jantar also have both values of 47 and $49 \mathrm{ppm}$ which are above the crustal average of $30 \mathrm{ppm}$. Only the farm soils of kuru Jantar mining site have $\mathrm{Zr}$ $183 \mathrm{ppm}$ above the crustal average of 165 ppm. Sn (values ranges from $4-7 \mathrm{ppm}$ above the crustal average of $2 \mathrm{ppm}$. Y ranges from $15-36 \mathrm{ppm}$ in farm soils in Kuru Jantar recording $36 \mathrm{ppm}$ above crustal average of $33 \mathrm{ppm}, \mathrm{Nb}$ ranges from 77 - 194 ppm with all values far above the crustal average of $20 \mathrm{ppm}, \mathrm{Sc}$ values all fall below the crustal average of $22 \mathrm{ppm}$. Be ranges from $1-4 \mathrm{ppm}$ with only soil from farm at Kokop mine site with value below the crustal average of 2.8. Index of geoaccumulation

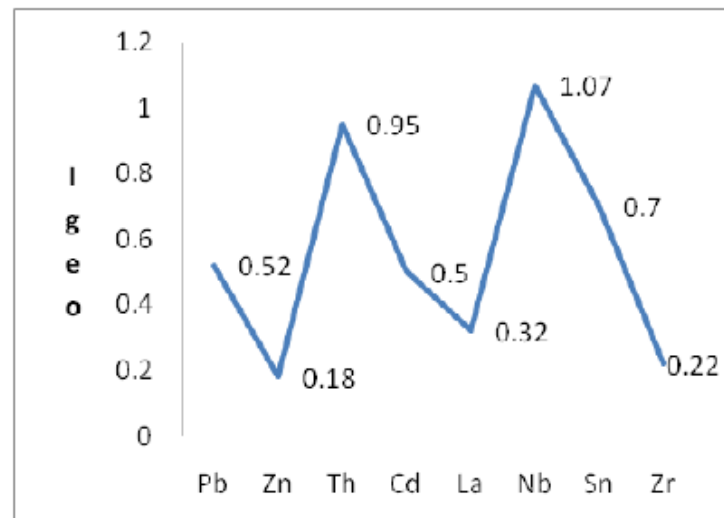

Fig 2: Igeo for some trace elements In farm soils at Kuru Jantar calculated (Fig. $1-4$ ) for some of the trace elements $(\mathrm{Pb}, \mathrm{Zn}, \mathrm{Th}, \mathrm{Cd}, \mathrm{La}, \mathrm{Zr}$, $\mathrm{Sn}, \mathrm{Y}, \mathrm{Nb}$, and $\mathrm{Be}$ ) have values ranging from $0.32-0.91,0.13-0.18,0.16-$ $1.65,0-0.50,0.09-0.31,0.10-0.02$, $0.40-0.70,0.07-0.22,0.77-1.95$ and $0.07-0.22$. Most values indicate uncontaminated to moderately contaminated soils with exception of the three sites. Both soils at Kuru Jantar farms and at the Kokop mining site are moderately contaminated with $\mathrm{Nb}$ as well as with Thorium (Th). The soil samples in the area are enriched with $\mathrm{Pb}, \mathrm{Zr}, \mathrm{Nb}$, $\mathrm{Cd}$ and $\mathrm{La}$ above the crustal average given by (Mason, 1966). Although calculated, index of geoaccumulation values for most elements in farm soils show uncontaminated to moderately contaminated with respect to Niobium and Thorium. These values of geoaccumulation are a source of concern as these values will steadily increase in the environment and will be a source of environmental hazard in years to come.

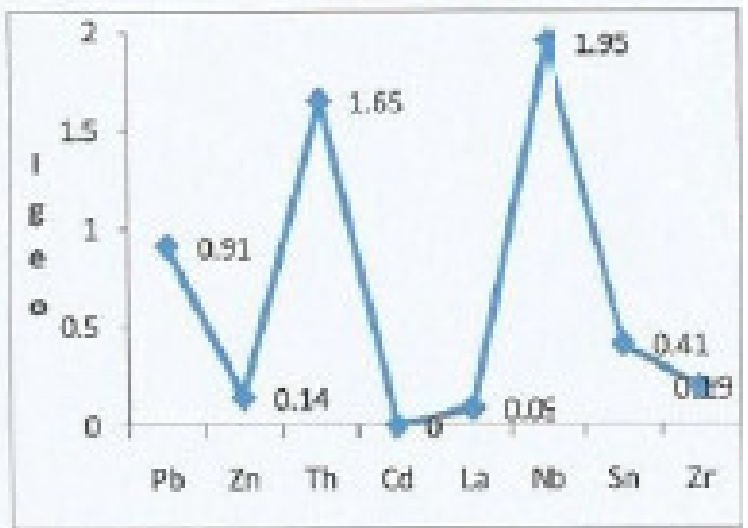

Fig 3: Igeo for some trace elements in farm soils at Kokop 


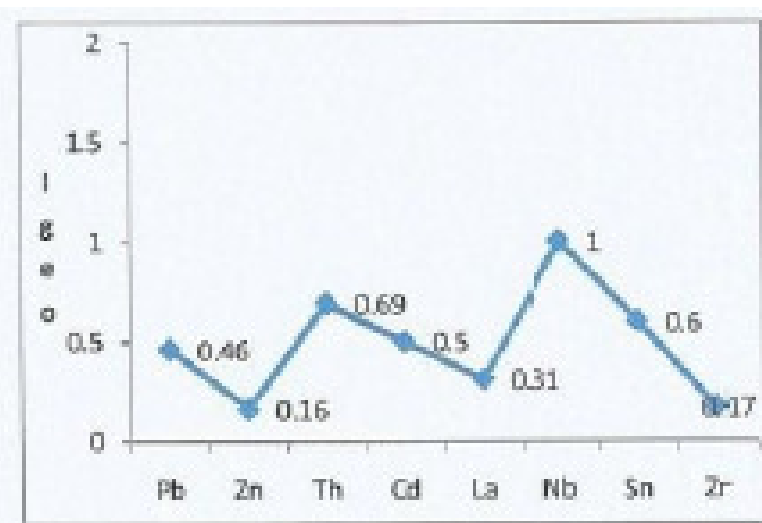

Fig 4: Igeo for some trace Elements in farm soils away from Kuru Jantar

Ranking of activities in the study area are presented in Table $3-7$. Abandoned lotto pits ranked first among the environmental problems, followed by erosion, mine dumps, siltations of streams and collapse of lotto pits (Table 3). The economic activities (Table 4) show mining as ranking first, followed by farming, petty businesses and transportations of goods and people ranking least. Surveyed responses on

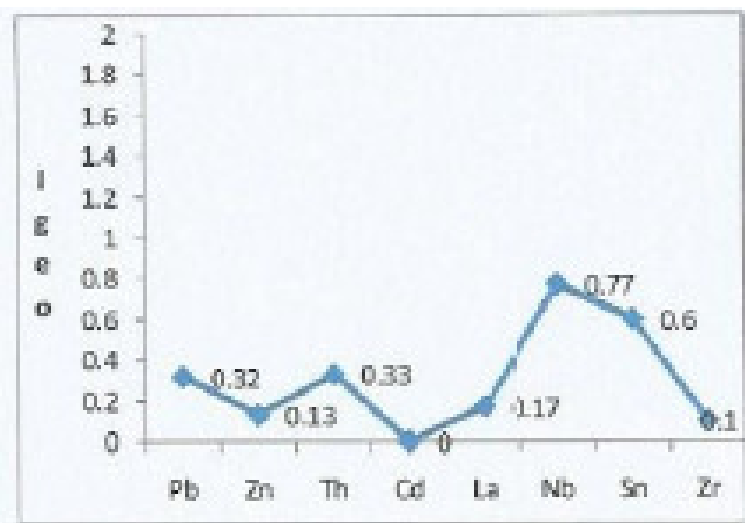

Fig 5: Igeo for some trace elements away from Kokop Mining site

disease (Table 5) commonly found among populations and prevalent drug problem showed that, HIV/AIDS, drugs, alcoholism and prostitution rank first. Population wise, men constitute the largest population in the area, followed by women and children constitute the least population. However, age wise, among the men people between ages $22-$ 40 are the largest.

Table 3: Environmental Problems Prevalent in the Study Area

\begin{tabular}{ll}
\hline Environmental Problem & Ranking \\
\hline Abandoned lotto pits & 1 \\
Erosion & 2 \\
Mine dumps and large ponds & 3 \\
Siltation of streams and Rivers & 4 \\
Collapsing Lotto Holes & 5 \\
\hline
\end{tabular}

Table 4: Per wise ranking of economic activities at Kuru Jantar

\begin{tabular}{ll}
\hline Economic Activity & Ranking \\
\hline Mining & 1 \\
Farming and livestock keeping (Goats, & 2 \\
Chicken) & \\
Petty businesses & 3 \\
Transport service & 4 \\
\hline
\end{tabular}


Table 5: Population at the Mine site

\begin{tabular}{llll}
\hline Population & Men & Women & Youth/Children \\
\hline 1,250 & 750 & 313 & 187 \\
& $60 \%$ & $26 \%$ & $14 \%$ \\
Age & $22-43$ & $22-43$ & $<22$ \\
& 500 & 200 & Males \& females \\
Age & $44-56$ & $44-56$ & \\
& 175 & 90 & \\
Main occupation & & & \\
Mining and farming & $100^{*}$ & $100^{*}$ & \\
Mining & $550^{*}$ & 135 & \\
Petty traders & $20^{*}$ & 60 & \\
Masons & $80^{*}$ & 30 & \\
\hline
\end{tabular}

(*) combination of multiple jobs e.g. mining, farming, masonry, petty trading.

Table 6: Surveyed Responses on Disease common Amongst Miners

\begin{tabular}{ll}
\hline Disease & Ranking \\
\hline STD/ H.I.V & 2 \\
Water borne (diarrhea dysentery) & 1 \\
Malaria & 3 \\
Worms (Tape worm) & 4 \\
\hline
\end{tabular}

Table 7: Surveyed responses on prevalent problems

\begin{tabular}{ll}
\hline Mining community & Ranking \\
\hline Alcohol, Drugs, Prostitution & 1 \\
Injuries & 4 \\
Reduced Household Labour & 5 \\
Erosion and Theft & 3 \\
Unemployment & 2 \\
\hline
\end{tabular}

\section{Discussion}

Environmental Impact: The active mining sites at Kuru Jantar and Kokop area show low to moderate levels of both rare earth and trace element concentrations in the waters and soils. All the surface water sources (Stream, dams, ponds) and those that are directly pumped out from the mine pits are enriched with respect to some of the trace and rare earth elements. The ground water sources have very low level concentrations of trace elements for example $\mathrm{As}, \mathrm{Co}, \mathrm{Cu}, \mathrm{Fe}$ and $\mathrm{Pb}$ compared to values given by $\mathrm{WHO}$ in
2004, but some elements are high e.g., Zinc and strontium. Probably the reasons for enrichment may be the active artisanal mining currently taking place in the area which have been mobilized and dispersed during the separation of the ores from the gangue through washing. Since the ores are restricted to certain areas within the overburden of the study area, it may probably be the reason for the trace and the rare earth elements in the ground waters (boreholes and hand dug walls).The over 900 abandoned lotto pits varying in depth from 10-15 meters 
are unmarked with no signs indicating their presence. Hence, their presences pose great threat to both humans and animals. The use of locally made sluice boxes has resulted in severe siltation of streams in the area.

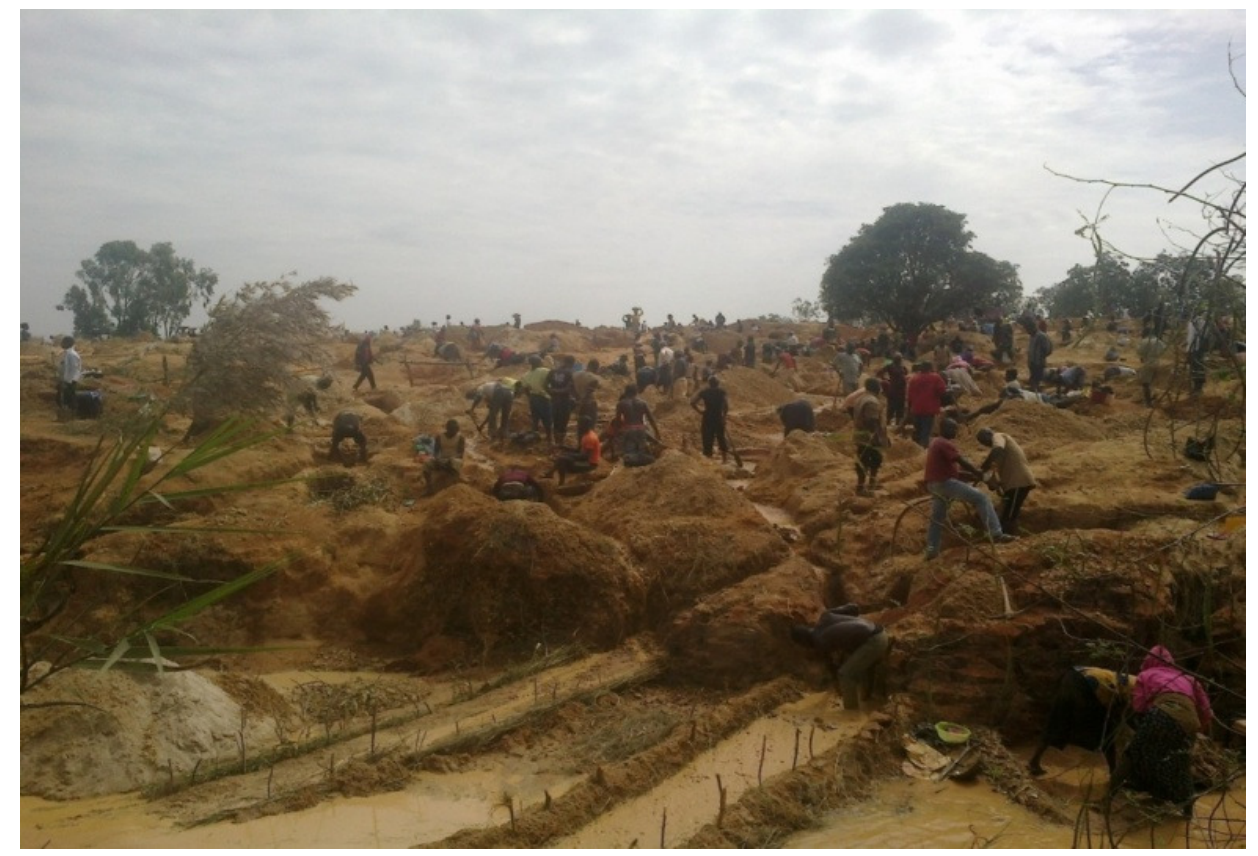

Plate 1: Tin seperation using ground Sluice Boxes

Diversion of streams from washing of the ores has resulted in the death of most aquatic lives in the area (Plates 1and 2). Removal of small trees and shrubs whose roots helps to bind soils has left the land bare making it susceptible to erosion (Stephen, 2008). Most of the lotto holes in the area are filled with stagnant water from rains and hence serve as breeding ground for disease vectors (both mosquitoes and houseflies) with high incidence of malaria and water borne disease such as dysentery. Indiscriminate dumping of mine tailings both in streams and on land makes the environment look dirty.The use of processing water from the mines for irrigation could accumulate potential toxic elements in soils, where plants could absorb and subsequently passed into the food chain. Similar areas around the Ray - Field tin mining sites showed $\mathrm{Pb}$ and $\mathrm{Cd}$ content in Cabbages, Green Pepper and Green Beans above the FAO recommended limit (Dibal and Yakubu, 2012). 


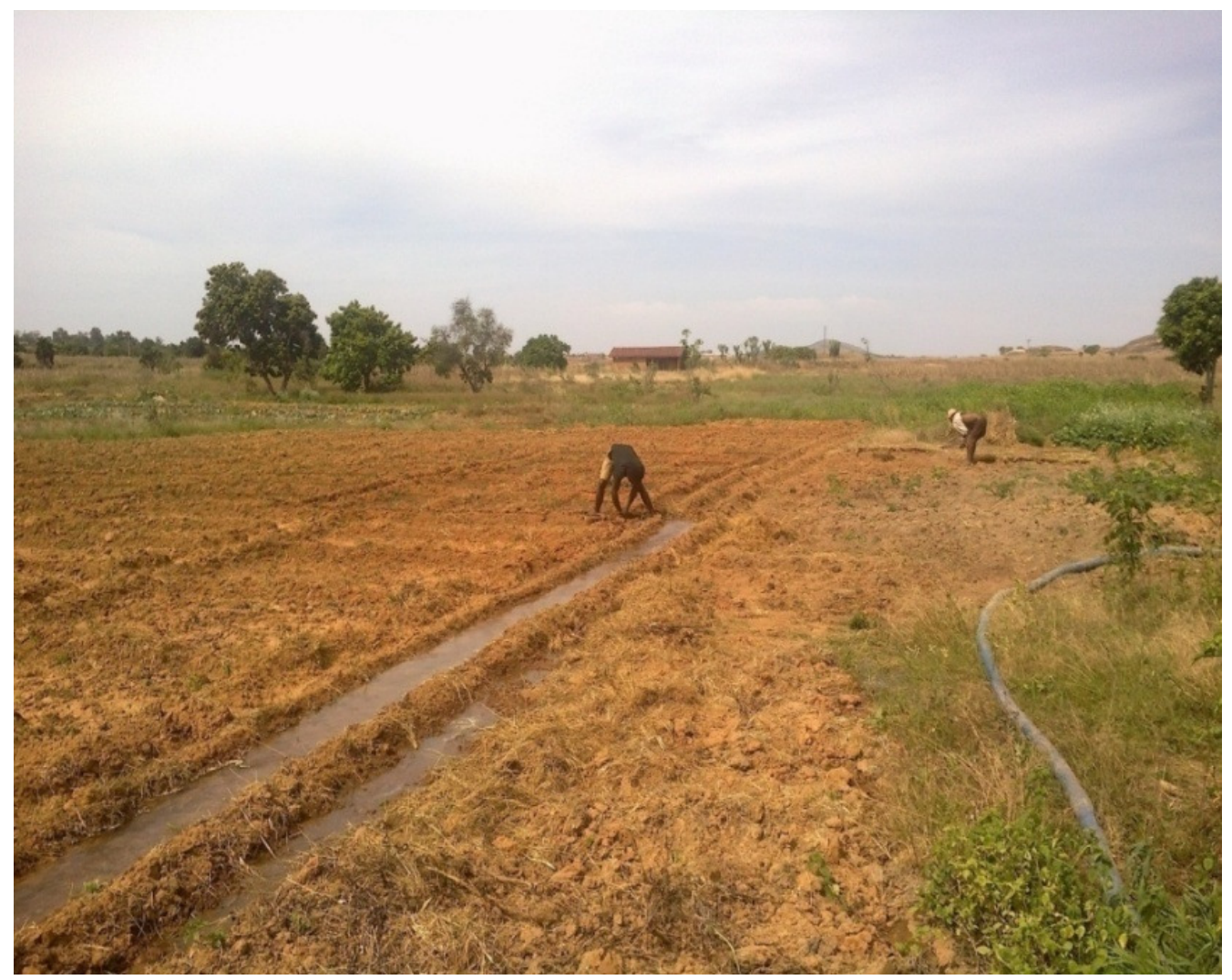

Plate 2: Utilisation of Mining Pond Water for Irrigation

Economic Effects of Artisanal Mining: The economic impacts of artisanal mining on the livelihood of the people are numerous. The activity has created a lot of employment opportunity for the people in the community. People who are not directly involved in mining are engaged in trading and transportation. The community has a business where they lease or rent landsfor mineral extraction (tin and columbite) and this helps to reduce social vices by promoting employment through entrepreneurship by employing unskilled labour force. A lotto pit produces between 10-12 tonnes of tin which yields 10-15 fifty kilogram bag weekly, shared amongst 8-10 people working as a group per hole. A $50 \mathrm{~kg}$ can be sold for as much as ( 20, 000- $\$ 30$, 000) twenty to thirty thousand naira (\$121-\$181) (Lekmang and Dibal, 2012). On the national level the export of these minerals may increase foreign exchange if properly managed. Worthy of note is that, the middle men who come to buy from these artisanal miners earned more than them at the end of the day.

Another problem, is inflation, the influx of mining money has brought about increase in food prices and goods. Food prices such as cooked rice at the mine sites are quite high ranging from $\$ 200$ - $\$ 300(\$ 1$ - \$2) and a bottle of coke (coca-cola) sells at about $\mathrm{N70}$ as against $\$ 50$ market price. 
Social Effects of Artisanal Mining: The mining in this area has resulted in people moving to the area from other places. Similar migration by people to mining areas has been reported (Bismarck and Darkoh, 2001; Stephen, 2008). This in turn has resulted in increased incidence of theft, prostitution, child labour, changes in indigenous life style and competition amongst locals. The displacement of people from arable farmlands due to perceived existence of minerals beneath the soil is a big problem, as inhabitants have to move to far places to obtain lands for farming (Kitula, 2005). On average, 6-8 deaths per year resulting from injuries due to tunnel/pit flooding and collapses have been recorded. Diseases commonly reported among the mining communities are sexually transmitted diseases such as gonorrhea, HIV/AIDS and dysentery. Drug problems such as the use of Indian hemp and alcoholism are common. Perhaps these are used as enhancers to reduce tiredness. Although the activity has provided means of livelihood for the locals, the cumulative economic gains are quite minimal, when compared to the risks of being trapped in a pit, exposure to toxic trace elements and the devastation to surrounding farmlands and other social vices.

\section{Conclusion}

The study investigated the environmental, economic and social impacts of artisanal mining in KuruJantar and environs area of Plateau State, Nigeria. Artisanal mining in the study area, contributes economically to the well being of the inhabitants but with corresponding environmental effects which is associated with land degradation, erosion, siltation of streams, trace element pollution and destruction of arable farmlands. Socially, inflation, theft, increase rate in schools drop outs, prostitution has increased in the communities. However, the government of Plateau State and Nigeria and other International bodies such as UNICEF can help improve the livelihood of these artisanal miners, by providing avenues where the locals can have access to professional advice and loans. This may improve the method of the mining, reduce the impact of the mining on the environment and reduce greatly the incidence of the social vices such as drug use and sexually transmitted diseases.

\section{References}

Bismarck, K.A and Darkoh, M.B.K. (2001). Socio-Economic and Environmental Impacts of mining in Botswana: A case study of the Selebi-Phikwe Copper-Nickel Mine. EASSRR vol. XVII, no. 2. Pp. 1- 41.

Buchanan, M.S., Macleod W.N. and Turner, D.C. (1971). The Geology of the Jos Plateau. Geological Survey of Nigeria Bulletin No.32.

Dibal, H.U. and Yakubu, J.A. (2011). Trace element contents of waters, soils and some edible cultivated vegetables around the abandoned mined ponds of the Ray-Field areas, Plateau State- Nigeria. $1^{\text {st }}$ IGCP/SIDA/UNESCO PROJECT 606. University of JohannesburgSouth Africa. Conference Paper.

Kitula, A.G.N. (2005). The environmental and socio-economic impacts of mining on local livelihood in Tanzania: A case study of Geita District. Journal of 
Cleaner Production Elsevier, 14: $405-414$.

Lekmang, I.C and Dibal, H.U. (2012). Economic, environmental and social impact of artisinal mining around Kuru-Jenta Village, BarkinLadi, Jos, Plateau State. $2^{\mathrm{ND}}$ IGCP/SIDA/UNESCO PROJECT 606.Nkwame Nkrumah University of Science and Technology Kumasi-Ghana. Conference paper, page 9

Macleod, W.N., Turner, D.C. and Wright E.P. (1971). The Geology of Jos Plateau. Geological Survey of Nigeria Bulletin, 32(1): 31 - 44.

Mason, B. (1966). Principle of Geochemistry, 3rd edition, John Wiley and sons, p. 329.

Mallo, S.J. (1999). The Nigerian Mining sector: An overview.Continental J. Applied sciences 7(1): 34-45.

Mallo, S.J. (2012). The Socio-economic impact of artisanal mining in Kuru (Naraguta sheet 168) Plateau State North Central Nigeria. Continental. $J$. Engineering Science, 7(3): 27-32.

Samuel, O., Precious, A.M., Meimuna, M.M., Fredrick, A.A., Shiloh, O., Sam, A. and Philip, O.Y. (2016). Assessing the Enviromental and
Socio-Economic Impacts of Artisanal Gold Mining on the Livelihoods of Communities in thr Tarkwa Nsuaem Municipality in Ghana. International Journal of Envronmental Research and Public health. Pp. 1-15.

Solomon, A.O. (2004). A study of Natural Radiation levels and Distribution of dose rates within the Granite province of Nigeria (Unpublished thesis for upgrading from Master of Philosophy to Doctor of Philosophy). Department of Geology and Mining, University of Jos, Nigeria.

Stephen, Y. (2008). Surface Mining and Economic impacts and Challenges. The Southern African Institute of Mining and Metallurgy. Pp. 181202.

Turner, D.C. (1976). Structure and petrology of the younger granite ring complexes of Nigeria edited by C.A Kogbe, Rock View (Nig) Ltd. P. 175.

W.H.O. (2006). World Health Organizations Drinking water standard (www.lenitech.com). 